\title{
Pengaruh Pemberian Pakan Buatan Berbasis Tepung Lamun Dan Fermentasi Ampas Kelapa Pada Kombinasi Yang Berbeda Terhadap Pertumbuhan Dan Sintasan Teripang Pasir (Holothuria scabra Jaeger)
}

\author{
[The Effect of Artificial Feeding Based on Seagrass Flour and Fermentation of Coconut Pulp \\ in Different Combination toward the Growth and Survival Rate of Cucumber (Holothuria \\ scabra)]
}

Muh. Ari Saputra, Indriyani Nur*, Abdul Muis Balubi

Program Studi Budidaya Perairan, Fakultas Perikanan dan Ilmu Kelautan, Universitas Halu Oleo JL. HAE Mokodompit Kampus Bumi Tridharma Anduonohu Kendari, Indonesia 93232

*Email korespondensi: indriyani_nur@uho.ac.id

\begin{abstract}
ABSTRAK
Penelitian ini bertujuan untuk mengevaluasi beberapa formula pakan berbasis tepung lamun dan fermentasi ampas kelapa terhadap pertumbuhan mutlak dan tingkat kelangsungan hidup teripang pasir. Tiga jenis pakan diujicobakan, yaitu pakan dengan kombinasi beberapa dosis tepung lamun dan fermentasi ampas kelapa, sedangkan pakan kontrol adalah bersumber dari kompos. Pakan kontrol adalah bentik yang dirangsang pertumbuhannya dengan kotoran ayam. Teripang pasir yang digunakan berbobot 7-60 g sebanyak 60 ekor, 5 ekor per wadah pemeliharaan. Benih teripang diberi pakan uji sekali dalam sehari pada sore hari. Percobaan dirancang dengan Rancangan Acak Kelompok terdiri atas empat perlakuan pakan dan tiga ulangan. Percobaan berlangsung selama 45 hari. Variabel yang diamati yaitu pertumbuhan mutlak, laju pertumbuhan spesifik, tingkat kelangsungan hidup dan kualitas air. Hasil penelitian menunjukan pemberian pakan buatan berbasis tepung lamun dan fermentasi ampas kelapa memberikan pengaruh yang nyata terhadap pertumbuhan mutlak dan laju pertumbuhan hari ke-45, namun memberikan pengaruh yang tidak berbeda nyata terhadap laju pertumbuhan spesifik pada hari ke-15 dan 30 serta tingkat kelangsungan hidup. Benih teripang pasir yang diberi pakan kontrol menghasilkan pertumbuhan mutlak tertinggi $(6,90 \mathrm{~g})$. Laju pertumbuhan spesifik berkisar antara $0,13-0,71 \%$. Sementara tingkat kelangsungan hidup berkisar antara 66,67-93,33\%. Kesimpulan yang daat ditarik pada penelitian ini bahwa diduga teripang pasir tidak dapat memanfaatkan pakan buatan dengan baik dibanding dengan pakan kontrol berupa bentik.
\end{abstract}

Kata kunci: pertumbuhan, lamun, fermentasi ampas kelapa, teripang pasir, Holothuria scabra.

\section{ABSTRACT}

This study had aim to evaluate several feed formulas based on seagrass flour and coconut pulp fermentation toward the growth and survival rate of sea cucumber. There types of feed were tested, namely feed with a combination of several doses of seagrass flour and fermented coconut pulp. The source of control feed was compost. The control feed was benthic with its growth was stimulated by compost of chicken manure. The sea cucumbers which used weighed 7-60 g as many as 60 fish, 5 fishes per rearing container. Sea cucumber seeds were fed by test feed once a day in the afternoon. The experiment was designed with a randomized group design consisting of four feed treatments and three replications. The experiment happened in 45 days. The variables observed in this study were absolute growth, specific growth rate, survival rate and water quality. The results of this results showed that artificial feeding based on seagrass flour and fermentation of coconut pulp had a significant effect on absolute growth and growth rate on the 45th day, but had no significant effect on the specific growth rate on the 15th and 30th days and the survival rate. Sea cucumber seeds which fed by control feed produced the highest absolute growth $(6.90 \mathrm{~g})$. The specific growth rate ranged from 0.13 to $0.71 \%$. Meanwhile, the survival rate ranged from 66.67 to $93.33 \%$. The conclusion that can be written from this study, namely it was assumed that the sea cucumber cannot consume optimally artificial feed compared to the control feed in the form of benthic.

Keywords: growth, seagrass, fermented coconut pulp, sea cucumber, Holothuria scabra

\section{PENDAHULUAN}

Teripang merupakan hasil laut yang bernilai ekonomis penting karena kandungan nutrisi dan metabolit sekunder yang dimiliki sehingga dapat dimanfaatkan untuk berbagai keperluan, termasuk untuk kosmetik, farmasi, bahkan untuk pengendalian penyakit pada udang budidaya (Nur, $d k k$., 2019). Selama ini teripang diperoleh dari aktifitas penangkapan, sehingga ketersediaan teripang di alam menjadi semakin langka sehingga budidaya semakin penting dilakukan sebagai alternatifnya (Wulandari dkk., 2016). Teripang pasir merupakan deposit feeder, pemenuhan nutrisinya akan sangat ditentukan oleh kelimpahan nutrisi dalam substrat atau tersuspensi. 
Pakan buatan sangat mempengaruhi pertumbuhan teripang pasir mengingat nutrisi yang terkandung di dalamnya. Bahan alam yang dapat dijadikan bahan pembuatan pakan teripang pasir adalah lamun dan fermentasi ampas kelapa. Pemberian pakan buatan berupa kombinasi pellet dan bubur lamun pernah duijicobakan untuk teripang hitam (Holothuria atra), namun tampaknya penyesuaian yang belum baik terhadap pakan tersebut mengakibatkan penurunan bobot tubuh organisme uji (Sholikhah, 2018).

Ekosistem padang lamun sebagai habitat Holothuria scabra umumnya ditumbuhi oleh berbagai jenis lamun antaralain Thalassia hemprichii, Enhalus acoroides, Cymodocea serrulata, C. rotundata, Halodule uni vervis,dan Syringodium isoetifolium. Setiap jenis lamun tentunya memiliki karakteristik khas dan menyediakan lingkungan mikroyang berbeda untuk larva (Indriana $d k k, 2016$ ). Daun lamun mengandung substansi yang bisa menginduksi metamorfosis dan menyediakan nutrisi yang dibutuhkan untuk pertumbuhan larva teripang pasir saat memasuki stadia juvenil (Indriana $d k k, 2016$ ).

Ampas kelapa adalah salah satu limbah pertanian yang dapat digunakan sebagai campuran bahan baku pakan ikan melalui proses penepungan. Hasil uji laboratorium, kandungan nutrisi tepung ampas kelapa yaitu protein 5,8\%, karbohidrat 37,5\%, lemak 16,4\%, dan serat kasar 31,7\%. Selain mudah diperoleh, penggunaan tepung ampas kelapa dalam campuran pakan ikan diharapkan dapat mengurangi penggunaan bahan baku pakan yang ketersediaanya terbatas dan mahal (Mutiasari $d k k$, 2017). Mempertimbangkan kandungan nutrisi yang dikandungnya, maka penelitian ini bertujuan untuk mengevaluasi beberapa formula pakan berbasis tepung lamun dan fermentasi ampas kelapa terhadap pertumbuhan mutlak dan tingkat kelangsungan hidup teripang pasir.

\section{BAHAN DAN METODE}

Penelitian ini dilaksanakan pada bulan Juni sampai dengan bulan Agustus 2019, yang bertempat di perairan Desa Tanjung Tiram, Kecamatan Moramo Utara, Kabupaten Konawe Selatan, Provinsi Sulawesi Tenggara.

\section{Pakan Uji}

Pakan uji disusun dengan rincian persentase yaitu Perlakuan A : 25\% Tepung lamun $+75 \%$ Fermentasi ampas kelapa, Perlakuan B : 50\% Tepung lamun $+50 \%$ Fermentasi ampas kelapa, Perlakuan C : 75\% Tepung lamun $+25 \%$ Fermentasi ampas kelapa, Perlakuan D : Kompos Kotoran Ayam (kontrol).

Pakan yang digunakan pada penelitian ini adalah pakan buatan berbentuk pasta dengan komposisi yang telah ditentukan pada Tabel 1. Penyediaan bahan untuk pembutan pakan yang sudah melewati proses penggilingan menjadi tepung. Semua bahan ditimbang sesuai dengan formulasi pakan dan ditempatkan dalam wadah atau baskom. Kemudian mencampur semua bahan baku hingga homogen. Mulai dari yang jumlahnya sedikit hingga yang terbanyak. Menambahkan air hangat kemudian mengaduk adonan pakan hingga tidak melengket di tangan. Kemudian adonan yang telah berbentuk pasta disimpan ke dalam toples yang telah diberi label dan disimpan pada tempat yang kering.

Pakan kontrol yang digunakan pada penelitian ini berupa plankton (pakan alami) dari kompos kotoran ayam sebagai makanan teripang pasir dengan komposisi terbesar yaitu fitoplankton kelas diatom atau bacillariophyceae sebesar 56\%. Untuk menstimulasi pertumbuhan diatom bentik, kotoran ayam dimasukkan ke dalam karung yang telah dilobangi dan diletakan pada setiap sudut kurungan dengan komposisi masingmasing karung sebanyak 2,5 kg yang ditanam dalam kurungan sebagai habitat diatom bentik (Padang $d k k .$, 2015).

\section{Persiapan Wadah}

Jumlah wadah yang akan digunakan pada penelitian ini yaitu 12 unit kurungan, masingmasing wadah memiliki ukuran $90 \mathrm{~cm}$ x $90 \mathrm{~cm}$ x $30 \mathrm{~cm}$. Rangka kurungan terbuat dari kayu dilapisi waring selanjutnya dipasangkan papan pada dinding media setinggi $25 \mathrm{~cm}$, fungsinya untuk mencegah arus mengeluarkan pasir dalam wadah pemeliharaan (Gambar 1). 
Tabel 1. Formulasi Pakan Uji pada Setiap Perlakuan.

\begin{tabular}{lllll}
\hline \multirow{2}{*}{ Bahan Baku Pakan } & \multicolumn{5}{c}{ Jumlah Bahan Baku Pakan pada Setiap Perlakuan (\%) } \\
\cline { 2 - 5 } & $\mathrm{A}$ & $\mathrm{B}$ & $\mathrm{C}$ & $\mathrm{D}($ Kontrol) \\
\hline Tepung Ikan (TI) & 30 & 30 & 30 & \\
Tepung Lamun & 7,5 & 15 & 22,5 & \\
Tepung Ampas Kelapa & 22,5 & 15 & 7,5 & \\
Tepung Kedelei & 30 & 30 & 30 & Kompos \\
Tepung Jagung & 5 & 5 & 5 & (Bentik/plankton) \\
Tepung Sagu & 3 & 3 & 3 & \\
Minyak Ikan & 1 & 1 & 1 & \\
Mineral Mix & 1 & 1 & 1 & \\
Total & $\mathbf{1 0 0}$ & $\mathbf{1 0 0}$ & $\mathbf{1 0 0}$ & \\
\hline
\end{tabular}

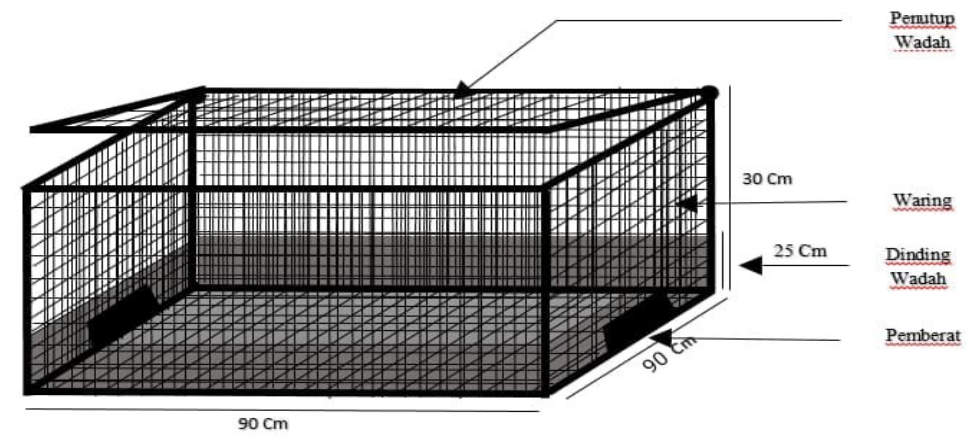

Gambar 1. Wadah yang digunakan untuk budidaya teripang pasir

\section{Pemeliharaan dan Pemberian Pakan}

Pemeliharaan dilaksanakan selama 45 hari. Teripang uji dipelihara menggunakan kurungan, sebanyak 60 ekor dimana 5 ekor setiap kurungan teripang uji. Setiap kurungan diberi label sesuai dengan perlakuan. Sebelum melakukan penebaran teripang uji ditimbang untuk memperoleh bobot awal. Penebaran dilakukan pada sore hari.

Pakan diberikan sekali dalam sehari yaitu pada sore hari (pukul 16.00 WITA) karena teripang lebih aktif makan pada malam hari (nocturnal) (Giri dkk.,2017). Untuk mengetahui pengaruh pakan percobaan yang diberikan, setiap 15 hari dilakukan penimbangan untuk mengetahui pertumbuhan harian.

\section{Rancangan Penelitian}

Penelitian ini menggunakan rancangan acak kelompok (RAK) dengan 4 perlakuan dan 3 ulangan.

\section{Variabel yang diamati}

\section{Pertumbuhan Mutlak}

Pertumbuhan mutlak dihitung dengan menggunakan rumus Hu et al. (2008).

$$
\mathrm{PM}=\mathrm{Wt}-\mathrm{W} 0
$$

Dimana: $\mathrm{PM}=$ pertumbuhan mutlak $(\mathrm{g}) ; \mathrm{Wt}=$ bobot rata-rata teripang pada akhir penelitian $(\mathrm{g})$; $\mathrm{W} 0=$ bobot rata-rata teripang pada awal penelitian (g)

\section{Laju Pertumbuhan Spesifik}

Laju Pertumbuhan Spesifik (LPS) dihitung menggunakan rumus Zonneveld $d k k$. (1991).

$$
\mathrm{LPS}=\frac{\mathrm{Ln} \mathrm{Wt}-\mathrm{Ln} \mathrm{W} 0}{\mathrm{t}} \times 100 \%
$$

Dimana : LPS = laju pertumbuhan spesifik (\%); Wt = bobot rata-rata teripang pada akhir penelitian $(\mathrm{g})$; 
$\mathrm{W} 0=$ bobot rata-rata teripang pada awal penelitian (g); $\mathrm{t}=$ lama pemeliharaan (hari).

\section{Tingkat Kelangsungan Hidup}

Tingkat kelangsungan hidup teripang uji dihitung dengan menggunakan rumus $\mathrm{Hu}$ et al. (2008).

$$
\mathrm{SR}=\frac{\mathrm{Nt}}{\mathrm{No}} \times 100 \%
$$

Dimana: $\mathrm{SR}=$ tingkat kelangsungan hidup (\%); $\mathrm{Nt}$ $=$ total teripang pada akhir penelitian (ekor); No $=$ total teripang pada awal penelitian (ekor)

\section{Kualitas Air}

Sebagai data penunjang dilakukan pengamatan dan pengukuran beberapa variabel kualitas air seperti : suhu, salinitas, $\mathrm{pH}$, kecerahan.

\section{Analisis Data}

Keseluruhan data kecuali kualitas air dianalisis dengan menggunakan analisis ragam dengan bantuan program SPSS versi 16,0, jika menunjukkan perbedaan yang nyata maka dilanjutkan dengan uji Duncan untuk mengetahui perbedaan antar perlakuan.

\section{HASIL}

\section{Pertumbuhan Mutlak}

Hasil analisis of varian (Anova) memperlihatkan bahwa perlakuan pakan berpengaruh nyata $(p<0,05)$ terhadap variabel pertumbuhan mutlak. Nilai rata-rata pertumbuhan mutlak pada teripang pasir $(H$. scabra) tampak pada Gambar 2.

\section{Laju Pertumbuhan Spesifik (LPS)}

Hasil analisis of varian memperlihatkan bahwa perlakuan pakan tidak berpengaruh nyata $(p>0,05)$ terhadap variabel pertumbuhan spesifik pada hari ke-15 dan ke-30, namun berpengaruh nyata $(\mathrm{p}<0,05)$ pada hari ke- 45 . Nilai rata-rata pertumbuhan spesifik pada teripang pasir (H. scabra) tampak pada Gambar 3.

\section{Tingkat Kelangsungan Hidup}

Hasil analisis of varian memperlihatkan bahwa perlakuan pakan tidak berpengaruh nyata $(p>0,05)$ terhadap variabel kelangsungan hidup. Nilai kelangsungan hidup pada teripang pasir (H. scabra) tampak pada Gambar 4.

\section{Kualitas Air}

Hasil pengukuran kualitas air selama penelitian disajikan pada Tabel 2 .

Tabel 2. Parameter Kualitas Air yang Diukur Selama Penelitian

\begin{tabular}{llc}
\hline No & Parameter & Hasil Pengukuran \\
\hline 1. & Suhu air & $27-29\left({ }^{\circ} \mathrm{C}\right)$ \\
2. & Salinitas & $29-31 \mathrm{ppt}$ \\
3. & Nilai $\mathrm{pH}$ & $6,8-7$ \\
4 & Kecerahan & $100 \%$ \\
\hline
\end{tabular}

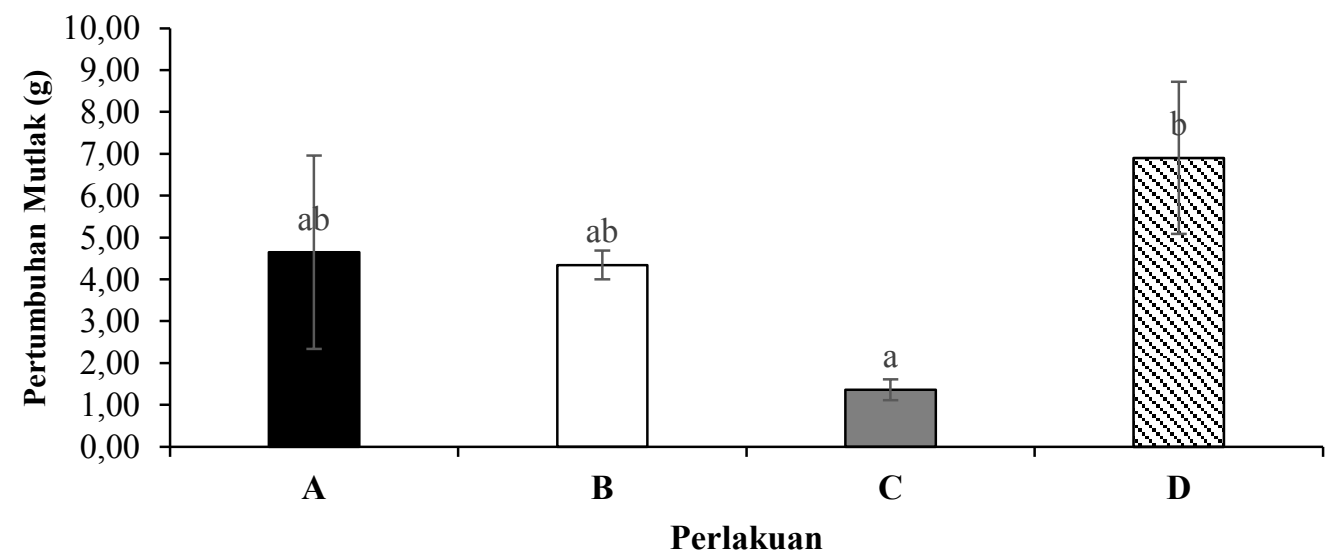

Gambar 2. Pertumbuhan Mutlak Teripang Pasir. Perlakuan A : 25\% Tepung Lamun $+75 \%$ Fermentasi Ampas Kelapa, Perlakuan B : 50\% Tepung Lamun + 50\% Fermentasi Ampas Kelapa, Perlakuan C : 75\% Tepung Lamun $+25 \%$ Fermentasi Ampas Kelapa, Perlakuan D : Bentik/Kompos (Kontrol). ${ }^{\text {a,b }}$ superscript yang berbeda menunjukkan perbedaan signifikan pada taraf $\alpha=0,05$. 


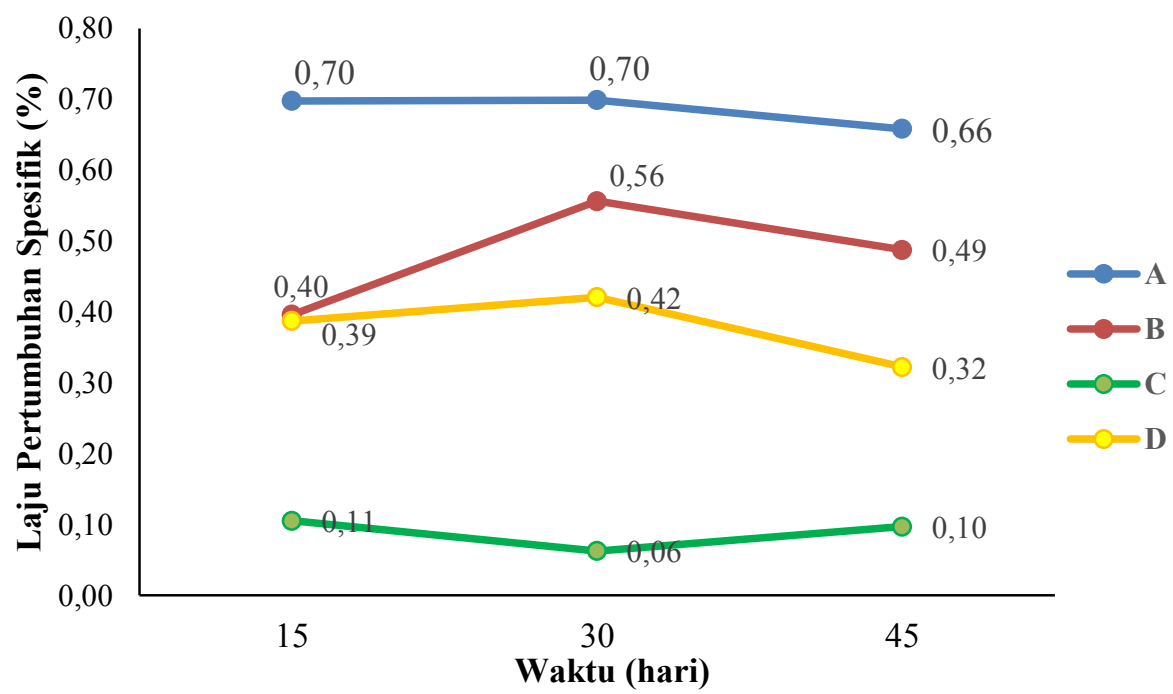

Gambar 3. Pertumbuhan Mutlak Teripang Pasir. Perlakuan A : 25\% Tepung Lamun $+75 \%$ Fermentasi Ampas Kelapa, Perlakuan B : 50\% Tepung Lamun + 50\% Fermentasi Ampas Kelapa, Perlakuan C : 75\% Tepung Lamun $+25 \%$ Fermentasi Ampas Kelapa, Perlakuan D : Bentik/Kompos (Kontrol).

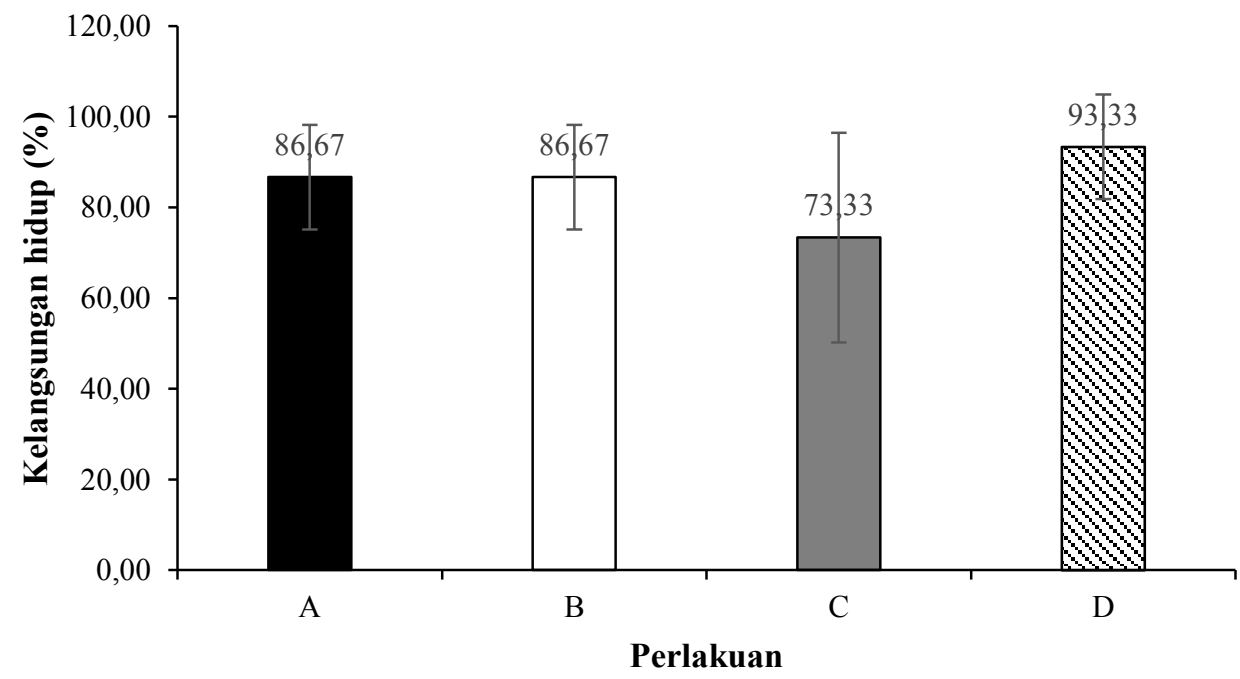

Gambar 4. Pertumbuhan Mutlak Teripang Pasir. Perlakuan A : 25\% Tepung Lamun + 75\% Fermentasi Ampas Kelapa, Perlakuan B : 50\% Tepung Lamun + 50\% Fermentasi Ampas Kelapa, Perlakuan C : 75\% Tepung Lamun $+25 \%$ Fermentasi Ampas Kelapa, Perlakuan D : Bentik/Kompos (Kontrol).

\section{PEMBAHASAN}

Pertumbuhan mutlak merupakan selisih pada biomassa awal dengan biomassa pada akhir pemeliharaan. Pertumbuhan dipengaruhi oleh beberapa faktor diantaranya faktor internal dan faktor eksternal. Faktor internal terdiri keturunan, umur, kemampuan memanfaatkan makanan. Sedangkan faktor eksternal terdiri dari kualitas air, kualitas dan kuantitas pakan serta ruang gerak (Gusrina, 2008).

Hasil penelitian bahwa pemberian pakan kontrol kompos kotoran ayam (perlakuan
D) menunjukan pertumbuhan mutlak tertinggi (6,90 g) dibandingkan dengan pemberian pakan buatan berbasis $25 \%$ Tepung lamun $+75 \%$ Fermentasi ampas kelapa (perlakuan A), 50\% Tepung lamun $+50 \%$ Fermentasi ampas kelapa (perlakuan B) dan 75\% Tepung lamun $+25 \%$ Fermentasi ampas kelapa (perlakuan C). Hal ini diduga pemberian kompos ayam yang mengandung bahan organik dapat menunjang pertumbuhan diatom bentik yang sesuai dengan kebutuhan dan makanan teripang pasir di alam. Hal ini dikuatkan dari hasil penelitian Yusnaini \& Nur (2020) yang menggunakan kompos 
kotoran ayam untuk menumbuhkan plakton sebagai pakan alami pada tambak udang. Selain itu, pernyataan Padang, $d k k$. (2011) bahwa teripang pasir merupakan organisme bentos yang cara makannya deposit feeding dapat memperoleh makanannya dari alam berupa plankton termasuk diatom bentik, dengan demikian untuk lebih mempercepat pertumbuhan diatom bentik yang menjadi makanan teripang pasir, dapat dirangsang dengan pemberian kotoran ayam yang akan mengalami proses dekomposisi menghasilkan nitrat dan fosfat bagi pertumbuhan diatom bentik. Sementara perlakuan yang diberi pakan $25 \%$ Tepung lamun $+75 \%$ Fermentasi ampas kelapa (perlakuan A), 50\% Tepung lamun + 50\% Fermentasi ampas kelapa (perlakuan B) menunjukkan hasil yang cukup tinggi yaitu $4,65 \mathrm{~g}$ dan 4,34 g. Hal ini diduga nilai karbohidrat yang tinggi yang terdapat pada ampas kelapa mampu dicerna baik oleh teripang, Menurut Mutiasari, dkk. (2017), bahwa ampas kelapa mengandung karbohidrat yang tinggi yaitu 37,5\%. Hal ini mampu membantu memenuhi kebutuhan energi teripang pasir. Pemberian pakan buatan 75\% Tepung lamun $+25 \%$ Fermentasi ampas kelapa (perlakuan C) menunjukan angka pertumbuhan yang lebih rendah dibandingkan perlakuan lainnya. Hal ini diduga akibat pemberian fermentasi ampas kelapa yang masih kurang memenuhi kebutuhan energi teripang pasir yang hanya $25 \%$ walaupun tepung lamun yang diberikan cukup tinggi yaitu $75 \%$. Hal ini didukung oleh Purawisastra dan Affandi (2006), yakni ampas kelapa mengandung serat galaktomanan sebesar 88,7 \%. dan telah dijelaskan sebelumnya oleh Purawisastra (2001), bahwa serat galaktomanan dapat menurunkan kadar kolesterol darah.

Pemberian pakan 25\% Tepung lamun + $75 \%$ Fermentasi ampas kelapa (perlakuan A) pada penelitian ini memiliki pertumbuhan yang lebih baik dibandingkan dengan pertumbuhan teripang pasir yang dipelihara di kurungan tancap yang diberi pakan daun lamun dan kotoran ayam, hal ini dibuktikan dengan penelitian padang $d k k$ (2015), terjadi penambahan berat badan rata-rata 8,86 gram selama 6 bulan pemeliharaan sedangkan penelitian ini memiliki nilai rata-rata pertumbuhan yang baik yakni 4,65 gram selama 45 hari pemeliharaan. Ini membuktikan bahwa pemeliharaan teripang pasir yang diberikan pakan $25 \%$ Tepung lamun $+75 \%$ Fermentasi ampas kelapa (perlakuan A) dapat memberikan pertumbuhan yang lebih baik. Hal ini menunjukan pakan buatan berbasis $25 \%$ Tepung lamun $+75 \%$ Fermentasi ampas kelapa (perlakuan A), dapat digunakan sebagai pakan teripang yang dapat menunjang pertumbuhan dan sintasan teripang pasir.

Laju pertumbuhan spesifik adalah laju pertumbuhan perhari, Laju pertumbuhan spesifik didukung oleh kemampuan memanfaatkan makanan. Hal ini sesuai pernyataan Padang (2015) bahwa keberhasilan mendapatkan makanan untuk dikonsumsi akan menentukan pertumbuhan suatu organisme.

Berdasarkan hasil penelitian yang dilakukan perlakuan laju pertumbuhan spesifik tertinggi ialah pada perlakuan A (25\% tepung lamun $+75 \%$ fermentasi ampas kelapa). Hal ini diduga akibat karena tingginya fermentasi ampas kelapa yang diberikan. Menurut Winarni (2019), bahwa ampas kelapa yang telah difermentasi menggunakan $R$. oryzae akan meningkatkan kandungan kadar protein yang terdapat dalam ampas kelapa. Protein yang terdapat pada ampas kelapa akan dipecah oleh kapang menjadi bagian-bagian yang lebih mudah larut, mudah dicerna, sehingga nitrogen (N) terlarutnya mengalami peningkatan. Selain itu, menurut Purawisastra (2001), bahwa ampas kelapa mengandung serat galaktomanan sebesar $61 \%$ yang dapat menurunkan kadar kolesterol darah dan sejalan dengan penelitian Pravitasari (2017), yaitu pertambahan bobot organisme uji dipengaruhi oleh kandungan serat kasar dalam pakan. Dengan demikian, pemberian ampas kelapa sangat menguntungkan bagi pertumbuhan teripang pasir yang dibudidayakan.

Penelitian ini memiliki laju pertumbuhan spesifik yang lebih baik dibandingkan dengan pertumbuhan teripang pasir yang dipelihara di kurungan tancap yang diberi pakan lamun dan kotoran ayam, hal ini dibuktikan dengan penelitian padang $d k k$ (2015), yang memiliki hasil penelitian nilai rata-rata pertumbuhan yakni $0,14 \%$ selama 6 bulan pemeliharaan, sedangkan penelitian ini memiliki nilai rata-rata pertumbuhan yang baik yakni $0,71 \%$, selama 45 pemeliharaan yang diberi pakan 25\% Tepung lamun $+75 \%$ Fermentasi ampas kelapa (perlakuan A) ini membuktikan bahwa 
pemeliharaan teripang pasir yang diberikan pakan buatan berbasis $25 \%$ Tepung lamun + $75 \%$ Fermentasi ampas kelapa dapat memberikan pertumbuhan yang lebih baik. Hal ini menunjukan pakan buatan berbasis $25 \%$ Tepung lamun $+75 \%$ Fermentasi ampas kelapa (perlakuan A), dapat digunakan sebagai pakan teripang yang dapat menunjang pertumbuhan teripang pasir.

Tingkat kelangsungan hidup merupakan kelangsungan hidup suatu jenis organisme dalam proses budidaya dari mulai awal organisme ditebar hinggga organisme akan dipanen. Tingkat kelangsungan hidup dipengaruhi oleh predator, kualitas air dan makanan. Hal ini sesuai pernyataan Padang (2015) bahwa tingkat kelangsungan hidup teripang pasir dalam wadah kurungan selain dipengaruhi oleh organisme predator juga dipengaruhi oleh parameter kualitas perairan serta ketersediaan makanan.

Hasil penelitian tingkat kelangsungan hidup tertinggi berada pada teripang pasir yang diberi pakan kontrol kompos kotoran ayam perlakuan D yakni 93,33\%, diikuti perlakuan A yang diberi pakan buatan berbasis $25 \%$ Tepung lamun $+75 \%$ Fermentasi ampas kelapa yakni $86,67 \%$, kemudian Perlakuan B 50\% Tepung Lamun $+50 \%$ Fermentasi Ampas Kelapa yakni $86.67 \%$ dan terendah pada teripang pasir perlakuan C yang diberi pakan $75 \%$ tepung lamun $+25 \%$ fermentasi ampas kelapa. Hasil Anova memperlihatkan bahwa variabel tingkat kelangsungan hidup tidak berpengaruh nyata dimana nilai sig $>0,05$. Hal ini diduga karena media pemeliharaan selama penelitian masih dalam kisaran optimal yang dapat menunjang pertumbuhan dan kelangsungan hidup teripang pasir. Hal ini sesuai dengan pernyataan Padang $d k k$. (2015), menyatakan bahwa tingkat kelangsungan hidup teripang pasir dalam wadah kurungan dipengaruhi oleh parameter kualitas perairan serta ketersediaan makanan.

Kualitas air merupakan faktor lingkungan yang sangat berperan penting dalam keberhasilan usaha budidaya perikanan, khususnya teripang pasir, sehingga dalam pengelolaannya harus sesuai dengan kebutuhan standar optimum untuk menunjang pertumbuhan. Kualitas air yang diukur yaitu suhu, salinitas, $\mathrm{pH}$, dan kecerahan. Hasil penelitian menunjukan parameter kualitas air (Tabel 4) selama masa pemeliharaan berada pada kisaran optimal yang dapat menunjang pertumbuhan dan kelangsungan hidup teripang pasir.
Suhu perairan merupakan parameter fisika yang mempengaruhi pola kehidupan biotic akuatik seperti penyebaran, kelimpahan dan mortalitas (Maharani, 2007). Suhu berpengaruh secara lansung terhadap proses metabolisme semua organisme laut. Suhu di lokasi penelitian berkisar antara $27-29^{\circ} \mathrm{C}$. Menurut Martoyo dkk. (2006) bahwa umumnya teripang dapat beradaptasi pada kisaran suhu $24-30^{\circ} \mathrm{C}$. Dengan demikian suhu yang ditemukan pada lokasi penelitian sesuai bagi kehidupan teripang.

Salinitas merupakan salah satu parameter kualitas air penting yang sangat berpengaruh pada keberhasilan pembenihan teripang. Di habitatnya, teripang diketahui hidup pada perairan karang dan berpasir umumnya salinitas di perairan tersebut adalah 20-35 ppt (Nur, 1987). Salinitas di lokasi penelitian yaitu 29-31 ppt. Menurut Darman, $d k k$. (2016), bahwa umumnya teripang dapat beradaptasi pada kisaran salinitas 27-31 ppt. Dengan demikian kisaran salinitas yang ditemukan ini masih layak untuk pertumbuhan teripang pasir.

Nilai $\mathrm{pH}$ mempengaruhi tingkat kesuburan perairan karena mempengaruhi kehidupan organisme di dalam perairan. Perairan yang asam cenderung menyebabkan kematian pada organisme air, hal tersebut disebabkan konsentrasi oksigen akan rendah sehingga aktivitas pernapasan tinggi dan selera makan berkurang (Kangkan, 2006). Derajat keasaman $(\mathrm{pH})$ di lokasi penelitian menunjukkan angka 6,8-7. Menurut Padang, $d k k$. (2017), kisaran optimum untuk budidaya teripang pasir ialah kisaran $\mathrm{pH}$ 7,9-8,14. Sedangkan menurut Kaenda, dkk. (2016), kisaran $\mathrm{pH}$ ialah 6-7. Dengan demikian kisaran $\mathrm{pH}$ yang ditemukan ini masih layak untuk pertumbuhan teripang pasir.

Tingkat kecerahan suatu perairan identik dengan kejernihan perairan yang bersangkutan. Pada perairan yang tingkat kecerahannya tinggi dapat dipastikan tersuspensinya partikel rendah dan kandungan bahan organiknya rendah pula. Tingkat kecerahan di lokasi penelitian 100\%, Menurut Sutaman (1993) syarat mutlak untuk budidaya teripang dalam parameter kecerahan perairan berkisar antara 50-150 cm. Dengan demikian tingkat kecerahan yang ditemukan di lokasi 
penelitian masih layak untuk pertumbuhan teripang pasir.

\section{KESIMPULAN}

Pakan buatan yang diujikan dalam bentuk pasta campuran tepung lamun dan fermentasi ampas kelapa belum mampu menunjang pertumbuhan teripang pasir $(H$. scabra Jaeger). Olehnya disarankan kepada pembudidaya teripang untuk menggunakan bahan organik berupa kompos kotoran ayam, karena dapat memberikan pertumbuhan mutlak dan kelangsungan hidup yang baik.

\section{REFERENSI}

Darman., Idris, M., \& Astuti, O. (2016). Pertumbuhan dan kelangsungan hidup teripang pasir (Holothuria scabra) yang dibudidayakan pada keramba jaring tancap. Jurnal Media Akuatika, 1, 76-84.

Giri, N.A., Sembiring, S.B.M., Marzuqi, M., \& Andamari, R. (2017). Formulasi dan aplikasi pakan buatan berbasis rumput laut untuk pendederan benih teripang pasir (Holothuria scabra). Jurnal Riset Akuakultur, 12(3), 263-273.

Gusrina. (2008). Budidaya Ikan. Departemen Pendidikan Nasional. Jakarta. $355 \mathrm{hlm}$.

Hu, Y., Tan, B., Mai, K., Ai, Q., Zheng, S., \& Cheng, K. (2008). Growth and body of juvenile white shrimp (Litopenaeus vannamei), fed different ratios of dietry protein to energy. Aquaculture Nutrition, 14, 4-506 p.

Indriana, I.F., Afrianti, Y., Hilyana, S., \& Firdaus, M. (2016). Preferensi penempelan, pertumbuhan, dan sintasan larva teripang pasir, Holothuria scabra pada substrat lamun yang berbeda. Jurnal Riset Akuakultur, 11(3), 249-258.

Kangkan, A.L. (2006). Studi Penentuan Lokasi untuk Pengembangan Budidaya Laut Berdasarkan Parameter Fisika, Kimia dan Biologi di Teluk Kupang, Nusa Tenggara Timur. Tesis Magister. Universiitas Diponegoro. Semarang.

Lawrence, J.M. (1987). A Functionnal Biology of Echinoderms. The Johns Hopkins University Press. $340 \mathrm{p}$.

Maharani, W.H. (2007). Kajian Kualitas Perairan di Pantai Kota Bandar Lampung Berdasarkan Komunitas
Hewan Makrobenthos. Tesis Megister. Universitas Diponegoro. Semarang.

Martoyo, J., Nugroho, A., \& Winanto, W. (2006). Budidaya Teripang. Edisi Revisi. Penebar Swadaya. Jakarta. 75 hal.

Mutiasari. W., Santoso. L., \& Utomo, D.S.C. (2017). Kajian penambahan tepung ampas kelapa pada ikan bandeng (Chanos chanos). Jurnal Rekayasa dan Teknologi Budidaya Perairan, 6(1), 684690.

Nur, B. (1987). Studi Kemungkinan Budidaya Teripang di Perairan Pulau Baranglampo Kotamadya Ujung Pandang. Skripsi. Jurusan Perikanan, Fakultas Peternakan Universitas Hasanuddin, Ujung Pandang. 47 hal.

Nur, I., Asnani, \& Yusnaini. (2019). Potensi ekstrak steroid dari teripang pasir (Holothuria scabra) dari Perairan Atowatu Kendari untuk pengendalian bakteri Vibrio harveyi. Jurnal Sains dan Inovasi Perikanan, 3(1), 26-31.

Padang, A., Lukman, E., \& Sangadji, M. (2015a). Pertumbuhan dan kelulusan hidup teripang pasir (Holothuria scabra) yang dipelihara di kurungan tancap (pen-culture). Jurnal Bimafika, 7(1), 782-786.

Padang, A., Lukman, E., Sangadji, M., \& Subiyanto. R. (2015). Pemeliharaan teripang pasir (Holothuria scabra) di kurungan tancap. Jurnal Agribisnis Perikanan, 9(2), 11-18.

Purawisastra, S., Affandi, E. (2006). Pengaruh suplementasi serat galaktomanan ampas kelapa terhadap penghambatan kenaikan kadar kolesterol darah. Bul. Penel. Kesehatan, 34(1), 20-29.

Purawisastra, S. (2001). Pengaruh isolat galaktomannan kelapa terhadap penurunan kadar kolesterol serum kelinci. Warta Litbangkes, vol.5 (3\&4).

Purwati, P. (2005). Teripang Indonesia: Komposisi jenis dan sejarah perikanan. Oseana, 30(2): 11-18.

Ruswahyuni. (2010). Populasi dan keanekaragaman hewan makrobenthos pada perairan tertutup dan terbuka di Teluk Awur, Jepara. Jurnal Ilmiah Perikanan dan Kelautan, 2(1): 11-20.

Rusyani, E., Dwiyanti, N., \& Erawati, L. (2003). Biologi Teripang Pasir 
(Holothuria scabra). Pembenihan Teripang Pasir: Seri Budidaya Laut, 7(11), $3-7$.

Sholikhah, N.L.M.A. (2018). Sintasan dan Pertumbuhan Induk Teripang Hitam Holothuria atra pada Persentase Pemberian Pakan Lamun dan Pelet yang Berbeda. Skripsi. Universitas Brawijaya.

Skewes, T., Dennis, D., Wassenberg, T.J., Austin, M., Moeseneder, C., Koutsoukos, A., Haywood, M., Pendrey, R., \& Bustamante, R. (2002). Surveying the distribution and abundance of Holothuria scabra (Sandfish) in Moreton Bay. Brisbane: CSIRO Division of Marine Research Final Report.

Storer, T.I.R.C., Stebbins, R.L., Usinger., Nybakken, J.W. (1979). General Zoology. McGraw-Hill Inc. 902 p.

Sutaman. (1993). Petunjuk Praktis Budidaya Teripang. Kanasius Anggota IKAPI, Yogyakarta.

Wulandari, U., Sulistyo, B., \& Hartono, D. (2016). Aplikasi SIG untuk analisis kesesuaian kawasan budidaya teripang pasir (Holothuria scabra) dengan metode penculture di Perairan Teluk Kiowa, Desa Kahyapu, Kecamatan Enggano. Jurnal Enggano. 1(1), 57-73.

Wulandari., Yudha, I.G., \& Santoso, L. (2018). Kajian pemanfaatan tepung ampas kelapa sebagai campuran pakan untuk ikan lele dumbo, Clarias gariepinus (Burchell, 1822). e-Jurnal Rekayasa dan Teknologi Budidaya Perairan, 6(2), 713718.

Yamin, M. (2008). Pemanfaatkan ampas kelapa dan ampas kelapa fermentasi dalam ransum terhadap efesiensi ransum dan income over feed cost ayam pedaging. Jurnal Agroland, 15(2), 135139.

Yonno, M.,Yusnaini., \& Balubi, A.M. (2016). Studi pertumbuhan dan tingkat kelangsungan hidup teripang pasir (Holothuria scabra Jaeger) yang dipelihara dengan sistem basket. Media Akuatika, 2(3), 106-115.

Yusnaini, Nur, I. (2020). The plankton abundance fluctuation in traditional ponds by the use of organic fertilizer from poultry manure. IOP Conf. Ser.:
Earth Environ. Sci., 465012041. doi:10.1088/1755-1315/465/1/011002

Zonneveld, N. E. A., Huisman, Boon, J.H. (1991). Prinsip Budidaya Ikan. PT Gramedia Pustaka Utama. Jakarta. 